\title{
Az improvizált robbanószerkezetek elleni védekezés irányai napjaink müveleti környezetében
}

\section{The Directions of Countering Improvised Explosive Devices at the Present Operational Environment}

Az improvizált robbanóeszközök alkalmazása a hadviselés történetében nem ismeretlen. Napjainkban azonban jelentös változások figyelhetők meg a hadviselésben, az indirekt eljárások mind jobban háttérbe szorítják a hagyományos vagy direkt eljárási módozatokat. A hadviselö felek közötti technológiai vagy müveleti eljárásokban tapasztalható különbségekáltalában aszimmetrikus hadviselést eredményeznek. Ugyanakkor, a rögtönzött robbanószerkezetek alkalmazását mind gyakrabban kapcsoljuk össze az aszimmetrikus hadviseléssel mint azt alapvetően meghatározó fegyver. A fegyver elleni védekezés mára egy komplex rendszerben épül fel, amelynek része az eszköz detektálása. Az improvizált robbanószerkezetek elleni védekezés fejlesztésének mozgatórugója a mozgásszabadság fenntartása, amely alapvetően befolyásolja a müveletek sikerét.

Kulcsszavak: hadviselés, fenyegetettség, improvizált robbanószerkezet, improvizált robbanószerkezet elleni tevékenység

The use of improvised explosive devices (IED) is not unknown in the history of warfare. Nowadays, however, significant changes can be observed in warfare, with indirect procedures increasingly pushing traditional or direct procedural modes into the background. Differences in technological or operational procedures between the warring parties usually result in asymmetric warfare. At the same time, the use of improvised explosive devices is increasingly being associated with

Habilitált címzetes egyetemi tanár, Nemzeti Közszolgálati Egyetem Hadtudományi Doktori Iskola és a Nemzeti Közszolgálati Egyetem Műszaki Doktori Iskola, külsős tanár, témavezető, e-mail: dr.kovacstibi61@gmail.com, ORCID: https://orcid.org/0000-0001-5987-8289

2 MH rendelkezési állomány, NATO Terrorizmus Elleni Védelem Kiválósági Központ, Képességfejlesztési Osztály, osztályvezető, e-mail: csurgo.attila@mil.hu, ORCID: https://orcid.org/0000-0002-6494-6490 
asymmetric warfare, since this is fundamentally influenced by this weapon. Countering the threat of this weapon is now incorporated in a complex system that includes device detection. The driving force behind the development of IED countering is the maintenance of the freedom of movement, which fundamentally affects the success of operations.

Keywords: warfare, threat, Improvised Explosive Device, Counter-improvised Explosive Device

\section{Bevezetés}

Az improvizált vagy más néven „házi” készítésű robbanószerkezet (IED)³ mint kifejezés először a brit katonai körökben jelent meg, az Ír Köztársasági Hadsereg (IRA)4 által különféle módon házilag barkácsolt robbanószerkezetek elnevezésére. Ugyanakkor a rögtönzött robbanószerkezetek mint az ellenség akadályozásának, lassításának eszközeit már az I. világháborúban is számos alkalommal alkalmazták a szemben álló felek. A gallipoli ütközet ${ }^{5}$ utáni visszavonulás során a brit, ausztrál és az új-zélandi csapatok is alkalmaztak úgynevezett booby trapeket vagy meglepőaknákat, amelyek robbanó- vagy esetenként más, sérülést okozó eszközt tartalmazó csapdák. A rögtönzött eszközöket a hátrahagyott raktárakban, illetve a kiürített védelmi állásaikba helyezték el, hogy azok akadályozzák az ellenséges csapatok előrenyomulását, ${ }^{6}$ ezáltal biztosítva időt a visszavonulásra. Azonban napjainkra az IED-t mind gyakrabban kapcsoljuk össze az aszimmetrikus hadviseléssel. ${ }^{7}$ Az IED az aszimmetrikus hadviselés leghatékonyabb fegyvere, hiszen, bár alapvetően harcászati szinten jelentős, de alkalmazásával akár stratégiai célok is elérhetőek. Hatékonyságát az iraki és az afganisztáni műveletekben bizonyította, amelyet a tapasztalatok alapján Barbero tábornok úgy jellemzett, hogy a műveleteket végrehajtó csapatoknál a pusztítás mértékét figyelembe véve, a 20. században a tüzérség okozta a legnagyobb veszteségeket, azonban a 21. században az IED vált a legpusztítóbb tüzfegyverré. ${ }^{8}$

A STANAG $2295^{9}$ úgy jellemzi az improvizált robbanóeszközöket, hogy lehetnek egyszerüek és akár könnyen előállíthatók, de akár tartalmazhatnak korszerü és bonyolult elektronikai kom-

Improvised Explosive Device angol kifejezés rövidítése.

Irish Republican Army angol kifejezés rövidítése.

5 A Gallipoli-félsziget ostroma 1915. február 19-től 1916. január 9-ig tartó csata volt, amely során a védekező török hadsereg sikerrel védte meg a Dardanellák tengerszorost a támadó brit és szövetséges erőkkel szemben.

6 Marc Tranchemontagne: The Enduring IED Problem, 2016.

7 Az aszimmetrikus hadviselés fogalma: Pontosan körvonalazott politikai célok érdekében folytatott, gyakran több szervezet ideológiai, vallási, etnikai közösségén alapuló katonai és nem katonai műveleteket, eljárásokat és módszereket alkalmazó közvetlen és közvetett hatásokra építő és egymás hatásait felerősítő, a biztonság különböző dimenziónak területét veszélyeztető harcmodor, főként harcászati eljárás, amelyek együttes hatásával kényszeríthetjük akaratunkat az ellenségre. Forrás: Resperger István - Kiss Álmos Péter - Somkuti Bálint: Aszimmetrikus hadviselés a modern korban. Kis háborúk nagy hatással. Budapest, Zrínyi, 2013. 23.

8 Michael Barbero altábornagy a Joint IED Defeat Organization (JIEDDO) igazgatója. Forrás: Rob Hyde-Bales: The improvised Explosive Device - a defining component of $21^{\text {st }}$ century conflict. Counter-IED Report, London, Delta Business Media Ltd., 2018. 17.

9 Az IED elleni védekezés NATO-doktrínája: Allied Joint Publication AJP-3.15. Edition C, Version 1, Allied Joint Doctrine for Countering Improvised Explosive Devices. NATO STANAG 2295. Brussels, NATO Standardization Office (NSO), 2016. 
ponenseket is. ${ }^{10} \mathrm{Az}$ IED az aszimmetrikus fizikai támadás számos formájának egy részhalmaza, amely lehetővé teszi a gyengébb fél számára, hogy folyamatosan csapásokat mérjen úgy, hogy közben nem kell döntő ütközetbe bocsátkoznia a magasabb fejlettségi szinten álló ellenfelével.11

Az IED az ellenfél mozgását, valamint manővereit akadályozza, amely a csapatok tevékenységének szerves része. Napjainkban a mozgás-manőverszabadság fenntartása a katonai műveletek egyik legfontosabb tevékenységévé vált. A biztonságos mozgási feltételek megteremtése igen komoly feladatok elé állítja a fegyvernemeket és szakcsapatokat egyaránt. Ugyanakkor látnunk kell, hogy az aszimmetrikus hadviselés kapcsán számtalan új lehetőség, módszer alakult ki a csapatok biztonságos mozgásának akadályozására, megnehezítésére. ${ }^{12} \mathrm{~A} 21$. századi aszimmetrikus mủveletekben a rögtönzött robbanószerkezetek alkalmazása döntően befolyásolja a mozgásés manőverszabadság biztosítását. Az erőfeszítések döntő többsége a műszaki csapatokra hárul, amelyek felderítik, hatástalanítják a mozgást megnehezítő akadályokat, helyreállítják az utakat, mútárgyakat, biztosítva ezzel a biztonságos mozgási feltételeket. A tanulmány a szerzők korábbi írásai, ${ }^{13}$ valamint a müveleti területeken szerzett tapasztalataik alapján bemutatja az IED-k detektálásának jelenlegi irányát, arra a kiindulási alapra építve, hogy a műveleti tempó, valamint a műveletek biztosítása érdekében végzett manőverek gyors, biztonságos végrehajtása szükségessé teszi az IED-k hatékony és fizikai érintkezés nélküli felderítését, semlegesítését.

\section{A hadviselés jellemzői napjainkban}

A 21. század háborúit vizsgálva a háború kettős természetének clausewitzi elkülönítéséből kiindulva megkülönböztetünk direkt és indirekt hadviselést. ${ }^{14}$ Míg az előbbi célja az ellenfél megsemmisítése, addig az utóbbi célja korlátozott, és alapvetően az ellenfél kifárasztására irányul, de ugyanakkor mindkettő a politika céljainak megvalósítási módja. A politikai célok elérése jelentős mértékben megváltozott mind a háború formáit tekintve, mind a felhasznált eszközök tekintetében az utóbbi évtizedekben. ${ }^{15} \mathrm{~A}$ felhasznált eszközök és módszerek változására Victor Morris is utal írásában, amikor a hadviselést két alapvető, hagyományos és irreguláris formára osztja. Jellemzésében az irreguláris hadviselést az állami és nem állami szereplők közötti

10 Lásd még: Kovács Zoltán: Az improvizált robbanóeszközök föbb típusai. Müszaki Katonai Közlöny, 22. (2012), 2. 37-52.

11 Allied Joint Publication AJP-3.15. Edition C, Version 1, Allied Joint Doctrine for Countering Improvised Explosive Devices. NATO STANAG 2295. (2016) i. m. 1. fejezet 1.1. (a szerzők fordítása).

12 Szabó Sándor-Kovács Tibor - Kovács Zoltán: Az utak, területek akadálymentesítése VII. Müszaki Katonai Közlöny, 26. (2016), 1. 2.

13 Szabó Sándor - Kovács Tibor - Kovács Zoltán: Az utak, területek akadálymentesítése III. Müszaki Katonai Közlöny, 25. (2015), 1. 4-18.; Szabó Sándor - Kovács Tibor - Kovács Zoltán: Az utak, területek akadálymentesítése IV. Müszaki Katonai Közlöny, 25. (2015), 2. 116-130.; Szabó Sándor - Kovács Tibor - Kovács Zoltán: Az utak, területek akadálymentesítése V. Müszaki Katonai Közlöny, 25. (2015), 3. 2-9.; Szabó Sándor - Kovács Tibor - Kovács Zoltán: Az utak, területek akadálymentesítése VI. Müszaki Katonai Közlöny, 25. (2015), 3. 10-20.; Csurgó Attila: A rögtönzött robbanószerkezetek által teremtett mủveleti környezet hatása a mozgásszabadságra, az erők megóvása érdekében végrehajtott fejlesztésekre. Honvédségi Szemle, 147. (2019), 6. 42-53.

14 Forgács Balázs: A háború és a politika viszonyrendszere. In Gőcze István (szerk.): A háború és a politika viszonyrendszere. Budapest, Dialóg Campus, 2017. 121.

15 Forgács (2017) i. m. 123-124. 
erőszakos harcként definiálja, amely a legitimitásért és az érintett lakosság felett gyakorolt befolyásért folyik. Az irreguláris hadviselés az indirekt megközelítést és az aszimmetrikus eszközök használatát részesíti előnyben. Az irreguláris hadviselés központi eleme minden olyan hagyományostól eltérő tevékenység, amely lehetővé teszi egy ellenállási mozgalom vagy felkelés számára a kormány vagy a megszálló hatalom megzavarását vagy megdöntését azáltal, hogy együttmüködik bármely kormányellenes erővel az általuk kontrolálni kívánt területen. ${ }^{16}$ Morris megállapításai egyértelmüen az Irakban és Afganisztánban szerzett tapasztalatait tükrözi. ${ }^{17}$

Az Irakban lejátszódó folyamatok alapos vizsgálata rámutat, hogy a 21. században a szemben álló felek közötti jelentős technológiai különbség a konfliktusok elhúzódását eredményezte. Az elhúzódó konfliktusok jellemzően a béke fenntartása és annak építése érdekében feladataikat végző erők elleni felkelés, ellenállás eredménye. A felkelők, tekintettel a jelentős humán erőforrás, valamint a technológiai különbségekre, a hagyományostól jelentősen eltérő formáját alkalmazzák a hadviselésnek. Az aszimmetrikus hadviselést Szendy a Hadelmélet és katonai müveletek címü könyvének első kötetében a hadviselés formájaként írja le, majd példákkal bizonyítja, hogy a különböző történelmi korokban az aszimmetria folyamatosan jelen volt a hadviselésben. ${ }^{18} \mathrm{~A}$ megállapítása alapján az aszimmetria a hadviselés megvalósulási módja, velejáró jellemzője. A könyv aszimmetrikusságról szóló szakaszát a következő gondolatokkal zárja le: „A hadviselés aszimmetrikusságának igazán érdekes és elemzésre érdemes iskolapéldája az eltérő hadikultúrák alapján szervezett és funkcionáltatott haderők, fegyveres erők közötti fegyveres küzdelem."199 A hadikultúrák tanulmányozásában irányadó Forgács Balázs 2009-ben íródott PhD-értekezése, ${ }^{20}$ amely Kovács Jenőre ${ }^{21}$ hivatkozva értelmezi a hadikultúrát: „Olyan társadalmi és katonai szellemi és anyagi alapfeltétel, adottság, amelyre ráépülnek az aktuális háború jellegéből, a haditechnika színvonalából, a hadszíntér-viszonyokból, a moráltól függő alakzatok. [...] A hadikultúra a társadalmi élet egészét (tudomány, művészet, oktatás, gazdaság stb.) áthatja." ${ }^{22}$ Kovács Jenő a hadikultúrákat három területre osztja: mozgáscentrikus, anyagcentrikus és gerilla-hadviselés. ${ }^{23}$ A gerilla-hadviselés, mint a háború jellege, már Ágh Attila könyvében ${ }^{24}$ is megjelenik, amelyben az 1945 utáni háborúkat mint modern „kisháborúkat” elemezve kategorizálja őket. Természetesen látnunk kell, hogy könyve a hidegháború végéhez közeledve íródott, a nagyhatalmak szembenállása, új fejlesztésű fegyvereik tesztelése és ter-

16 R. Victor Morris: Grading Gerasimov: Evaluating Russian Nonlinear War Through Modern Chinese Doctrine. Small War Journal, 2015.

17 Victor Morris az irreguláris hadviselés és az abból származó fenyegetések elhárítására szakosodott oktató az USA Összhaderőnemi Többnemzeti Felkészítési Központjában - JMRC Grafenwoehr, Németország.

18 Szendy István: Hadelmélet és Katonai Müveletek. I. kötet. A katonai müveletek elmélete és gyakorlata. Budapest, Nemzeti Közszolgálati és Tankönyvkiadó, 2013. 140-141.

19 Szendy (2013) i. m. 142.

20 Forgács Balázs: Napjaink hadikulturái (A hadviselés elmélete és fejlődési tendenciái a modern korban). Doktori értekezés, ZMNE-KLHK/HDI, 2009.

21 Kovács Jenő altábornagy (1929-1996) katonai vezető és teoretikus, fő müve: Magyarország katonai stratégiája. Forgács Balázs: In memoriam Kovács Jenő. Hadtudomány, 19. (2009), 1-2. 105-112.

22 Forgács (2009) i. m. 41.

23 Forgács (2009) i. m. 42.

24 Ágh Attila: Konfliktusok, háborúk. Budapest, Zrínyi, 1989. 
mészetesen a háború megvívására kidolgozott elméletek tesztelése is, a megvívott kisháborúk során valósult meg. Ágh Attila négy típusú háborút (vagy konfliktust) különböztet meg: ${ }^{25}$

1. Az új konvencionális kisháború, amelynek okaként az időszakban létrejövő regionális középhatalmakat jelöli meg. E típusú háborúkra jellemző, hogy reguláris erők vívják, a korszerű haditechnikának döntő jelentősége van, illetve a felek stratégiát követnek, és a frontvonal, valamint a hátország jól elkülönül egymástól.

2. A nem konvencionális háború. Okaként annak elhúzódó jellegét jelöli meg, és bár a jellemzői között megtalálhatjuk a reguláris erőket és a stratégiát is, elhúzódó jellege miatt megjelenik a gerillaháború.

3. A destabilizációs háború, amelyben már a konfliktus jellegét a nem katonai eszközök alkalmazása jellemzi. Továbbra is elhúzódó háborúról beszélünk, de alapvetően az ellenálló felek közötti front nem létezik, továbbá szinte minden eszköz megengedett a társadalmi, gazdasági, politikai destabilizáció érdekében. Fontos, hogy a felek közötti jelentős katonai aszimmetria ellenére a konfliktus kimenetele változó volt.

4. Az utolsó kategóriát már nem is háborúként, hanem anómiás ${ }^{26}$ konfliktusként azonosítja. Az összecsapások gyakorlatilag leszükülnek ösztönös rendezetlen és váratlan politikai és/vagy fegyveres erőszakra. Az ilyen jellegü konfliktusok tulajdonságai között megtalálhatjuk az idegengyülöletet, a vallási fanatizmust és nem utolsósorban az etnikumok közötti ellentétet.

A fentiek alapján a nem konvencionális háborúk ismérvei között is megjelenik a gerillaháború mint a hadikultúrák egyik formája, ezért jelen korunk összecsapásainak mondhatjuk anómiás konfliktusai (Afganisztánban, Irakban vagy Szíriában kialakult) aszimmetrikus összecsapásainak vizsgálata szükséges. Az aszimmetria értelmezése érdekében fontos tisztázni az aszimmetrikus hadviselés fogalmát: „Pontosan körvonalazott politikai célok érdekében folytatott, gyakran több szervezet ideológiai, vallási, etnikai közösségén alapuló katonai, és nem katonai műveleteket, eljárásokat és módszereket alkalmazó közvetlen és közvetett hatásokra építő és egymás hatásait felerősítő, a biztonság különböző dimenziónak területét veszélyeztető harcmodor, főként harcászati eljárás, melyek együttes hatásával kényszeríthetjük akaratunkat az ellenségre."27

Az aszimmetrikus hadviselés megfogalmazása egyértelműsíti, hogy jelen korunk egyik hadviselési formájának megértéséhez a fogalomban rejlő összefüggések értelmezése szükséges. Tehát a minden tekintetben „gyengébb” fejlettségi szinten lévő fél az egyszerűen végrehajtható mủveletek széles tárházát használja céljai elérése érdekében. Vagyis az aszimmetrikus hadviselésre ugyanúgy jellemzőek az egyszerüen végrehajtható müveletek, mint a rendelkezésre álló anyagi erőforrások kihasználásával előállított egyszerű, de hatékony fegyverek. Az improvizált vagy házi készítésű robbanószerkezetek alapvetően könnyen és olcsón előállíthatók, ezáltal gyorsan meghatározó elemeivé váltak a 21. századi aszimmetrikus konfliktusoknak.

\footnotetext{
Ágh (1989) i. m. 178-190.

Anomosz, görög szó, jelentése: rendezetlen.

Resperger (2013) i. m. 23.
} 


\section{21. századi konfliktusok meghatározó fegyvere}

Az okokat keresve, hogy az IED miként válhatott a 21. századi konfliktusok legpusztítóbb tűzfegyverévé, az Irak ellen 2003. március 20-án megindított 2. öbölháborúba ${ }^{28}$ kell visszamenünk. Kevesebb mint két hónappal később az Amerikai Egyesült Államok elnöke, George W. Bush, 2003. május 1-jén már bejelentette az Irak ellen vívott háború lezárását. ${ }^{29}$ Szinte ugyanakkor megkezdődött a harcokban részt vevő csapatok kivonása. A tengerészgyalogság erőinek kivonása októberben fejeződött be, de novemberben már telepítették is vissza őket. A csapatok kivonását követő gyors visszatelepítésére a koalíciós erők által létrehozott hatóság május 23-i döntése volt a magyarázat. A döntés, amely megszüntette Szaddám Husszein, Irak korábbi vezetőjéhez hủ katonai, biztonsági és hírszerző apparátusát. ${ }^{30}$ Ez egy váratlan kihívás elé állította a koalíciós erők vezetését. Az iraki biztonsági erők feladatainak átvétele nem volt tervezett, és amint az gyorsan kiderült, a győztes erők nem rendelkeztek a szükséges erőforrásokkal a feladatok átvételére. Továbbá a megszüntetett szervezetek alkalmazottai (általában a muszlim vallási felekezethez tartozó szunniták) többnyire katonák és rendörök, fizetetlen munkanélkülivé váltak. Ezáltal munka nélkül maradt jónéhány jól képzett elektronikai és tüzszerészszakember is. Tovább fokozta a gondokat, hogy a korábban az iraki hadsereg által jól őrzött fegyver-, lőszerés robbanóanyag-raktárak is őrizetlenül maradtak.

Viszont a koalíciós csapatok nem rendelkeztek a feladatok átvételéhez szükséges erőkkel. Ezt a biztonsági vákuumot használta ki az „al-Káida” Irakban tevékenykedő szárnya, ${ }^{31}$ amely tárt karokkal fogadta a fegyveres harcra kiképzett munkanélkülieket. Hyde-Bales írásában úgy fogalmaz, hogy ez volt az ISIL ${ }^{32}$ valódi születése. ${ }^{33}$ A fent említett események oda vezettek, hogy jól felfegyverzett felkelők és a korábbiaknál jelentősen pusztítóbb IED-k jelentek meg. Ezek az IED-k már nemcsak az Irakban állomásozó koalíciós erőkre, de az Afganisztánban tevékenykedő csapatokra is valódi veszélyt jelentettek, amely súlyos következményekkel járt, hiszen az iraki hadszínterén megjelent szakértelem rövid idő alatt megjelent Afganisztánban is. ${ }^{34}$

Az IED-k hatékony tűzfegyverré válását jellemzi a CNN 2006. január 6-i riportja, amely rámutat, hogy csak ezen az egy napon 134 civil és katonai áldozata volt az Irak-szerte elkövetett IED-támadásoknak. ${ }^{35}$ Ugyanezen riport szerint az USA veszteségei ekkorra már 2187-re emelkedtek, amelyek csak fokozódtak, 2007 elejére az „elesettek” száma meghaladta a 3000 főt. Ugyanakkor a teljes koalíciós erők vesztesége 2003. május 1-jén, az USA elnökének bejelentésekor még csak 150 fö volt. ${ }^{36}$

28 Irak felszabadítása érdekében indított műveletek összesége 2003. 03. 20 és 2011. 12. 18. között (Operation Iraqi Freedom/Second Persian Gulf War), amely 2. öbölháborúként vált ismertté. Operation Iraqi Freedom/Second Persian Gulf War. Britannica.

29 „Mission Accomplished”. Telegraph.

30 Fateful Choice on Iraq Army Bypassed Debate. The New York Times, 2008.

31 Militáns szunnita hálózat, amely 2004-ben jelent meg Irakban. Felkelést robbantott ki az Irakot elfoglaló koalíciós erőkkel, valamint a síita többségü iraki kormány ellen. Al-Qaeda. Britannica.

32 Islamic State in Iraq and Syria angol kifejezés rövidítése, 2014-től Iszlám Állam néven vált ismertté.

33 Hyde-Bales (2018) i. m. 20.

34 The Taliban, regrouped and rearmed. The Washington Post.

35 At least 134 killed in attacks across Iraq. CNN.com, 2006.

36 Operation Iraqi Freedom/Second Persian Gulf War. Britannica. i. m. 
Az IED 21. századi aszimmetrikus konfliktusok meghatározó elemévé válását a jellemzőinek vizsgálatával bizonyítjuk. Az improvizált robbanószerkezet számos olyan jellemzővel rendelkezik, amely lehetővé teszi, hogy hatékonyabb és hatásosabb legyen, mint a hagyományos fegyverek. A szerzők kutatómunkája és személyes tapasztalatai alapján ezek a jellemzők:

1. Egyszerűen, kevés anyagi ráfordítással, akár kereskedelmi forgalomban kapható anyagokból előállítható, ezzel megteremtve a lehetőségét, hogy nem állami szereplők jelentős források nélkül is elő tudják állítani.

- Az EOD COE által a házi készítésű robbanószerkezetek tanfolyamának bevezetőjében az előállítás helyszínét a következőképpen jellemzi: „A házi készítésű robbanóanyagok laboratóriuma hasonlíthat egy »csináld magad« garázshoz, de nézhet ki úgy is, mint egy piszkos konyha, ahol közös konyhai alapanyagok és edények vannak fözéshez vagy sütéshez." ${ }^{37}$

2. Megsemmisítő hatása kiegyenlíti a drágább, hatásosabb hagyományos fegyverek előnyeit, amelyet jól példáz a tanulmányban referenciaként felhasznált CNN-riport.

3. A kialakítás és müködtetés számtalan variációja, amely jelentősen megnehezíti az ellenük való védekezést.

- Az IED kategóriákba sorolásának számos módja van. A szerzők által alkalmazott módszer az indítás módja szerinti kategorizálás, amely alapvetően három csoportba sorolja a rögtönzött robbanószerkezeteket, viszont a csoportokon belül a kialakítás többféle módja lehetséges: ${ }^{38}$

a) Időzített indítás,

b) Távirányított indítás,

c) Áldozat által indított.

4. A telepítésére, elhelyezésére jellemző nagyfokú környezeti rugalmasság, amely megnehezíti az eszköz felderítését, észlelését.

5. Nagyságának, pusztító erejének, azaz méreteinek kialakítása teljesen felhasználó- és/ vagy feladatfüggö.

- A katonai eredetű IED hatásfokának gyakorlati bemutatására, a Magyar Honvédség újdörögdi gyakorlóterén (romváros) városi környezetben, az MH 1. HTHE tűzszerészei bemutatták egy 82 mm-es aknavetőgránát IED-ként kifejtett hatását. A gránát körülbelül 3,5 kg tömegü, a benne található robbanóanyag mennyisége kevesebb mint $40 \mathrm{dkg}$, ugyanakkor a robbantásakor kifejtett hatása mégis figyelemre méltó. A robbanás repeszhatása 25 m-es körben súlyos életveszélyes sérüléseket okozott az imitációs célanyagban, még a második emeleti ablakokban elhelyezett célanyagban is több repeszt találtunk. ${ }^{39}$

6. A fegyver alkalmazása nem szükségszerüen jár együtt az alkalmazó kilétének felfedésével.

37 NATO Tűzszerész kiválósági központ. (EOD COE Trencin, Szlovákia) Házi készítésű robbanóanyagok tanfolyama - Basic (HME-B) Course 2019. OED COE.

38 Kyle Fowl - Roger Davies: What are IEDs? A review of the different types of IEDs that exist with a focus on recent developments in IED usage. AOAV, 2016.

39 A hatásbemutatóról készült film, amely DVD-melléklete a Bucsák Mihály et alii: 70 év az életveszélyárnyékában. A magyar tüzszerész- és aknakutató alakulatok története 1945-2015. Budapest, Zrínyi, 2015. könyvnek. 
7. Az alkalmazó számára a csapásmérés (az eszköz felrobbantása) kisebb veszélyekkel jár, mint egy fegyveres támadás, rajtaütés végrehajtása.

8. Kiszámíthatatlan alkalmazása műveleti szinten megnehezíti, akadályozza az erők megóvását és utánpótlással történő ellátását.

9. Alkalmazása általában nagyfokú sajtónyilvánosságot generál, amely stratégia következményekkel járhat.

- A következmények jellemzésére Somkuti a doktori értekezésében a következőképpen fogalmaz a Madridban vagy Londonban elkövetett robbantások stratégiai jelentőségét hangsúlyozva, hogy azért jelentenek új korszakot „mert az adott ország fővárosára, vagy szimbólumára mértek csapást. Az aszimmetrikus hadviselés (elsősorban gerillaháború) eddig csak az expedíciós, esetleg megszálló csapatokat fenyegette. A globalizáció mellékhatásaként a civilek között megbújó támadók számára egyetlen polgár sincs »lőtávolságon« kívül."40

Mindezek alapján megállapítható, hogy az IED fegyverként történő alkalmazása adott esetben lehetőséget teremt a gyengébb fél számára, hogy stratégiai jelentőségű sikereket érjen el. Ugyanakkor jellemzői teszik az aszimmetrikus hadviselés meghatározó fegyverévé.

\section{Az IED elleni védekezés}

Az IED-problémára irányuló kutatások nagy része az elmúlt évtizedekben az aknák felkutatásának problémájában gyökerezik. A telepített aknák veszélyének elhárítása gyakran a hidegháború korában érvényes konvencionális katonai forgatókönyvek kontextusában történt, ahol az aknákat a konfliktusban részt vevő csapatok, általában a korra jellemző doktrína szerint alkalmazták az ellenfél mobilitásának akadályozása érdekében. Az aknákból származó veszélyek kezelése gyakran csak a felderítésre, a semlegesítésre vagy a védelemre, a modern szóhasználatban az eszköz legyőzésére korlátozódott, állapította meg a témával kapcsolatos kutatásokat végző multinacionális csoport. ${ }^{41}$ Megállapításuk, hogy a hagyományosan előállított és telepített aknák felderítésétől eltérően a házi készítésű robbanószerkezetek esetében az eszköz alkalmazását követően a helyszín pontos elemzésével lehetőség nyílik a szerkezet előállításában részt vevő hálózat felszámolására. Az eszköz előállítására létrehozott hálózatot, amely magában foglalja a finanszírozót, az ellátót, a szállítót, az eszköz készítőjét, az eszköz alkalmazásának tervezőjét, az eszköz telepítőjét, valamint az eszköz működtetőjét kell felszámolni, ezáltal megakadályozva az eszköz alkalmazását. A folyamat működését az 1. ábra szemlélteti.

40 Somkuti Bálint: A negyedik generációs hadviselés-az érdekérvényesítés új lehetőségei. Doktori értekezés. Budapest, NKE, HHK, HDI, 2012. 48.

41 A kutatásban részt vevő szervezetek: Defence R\&D Kanada, TNO Defence, Security and Safety, Hollandia, Swedish Defence Research Agency, Svédország, Norwegian Defence Research Establishment, Norvégia. 


\section{AZ IED ELLENI HARC FOLYAMATA}

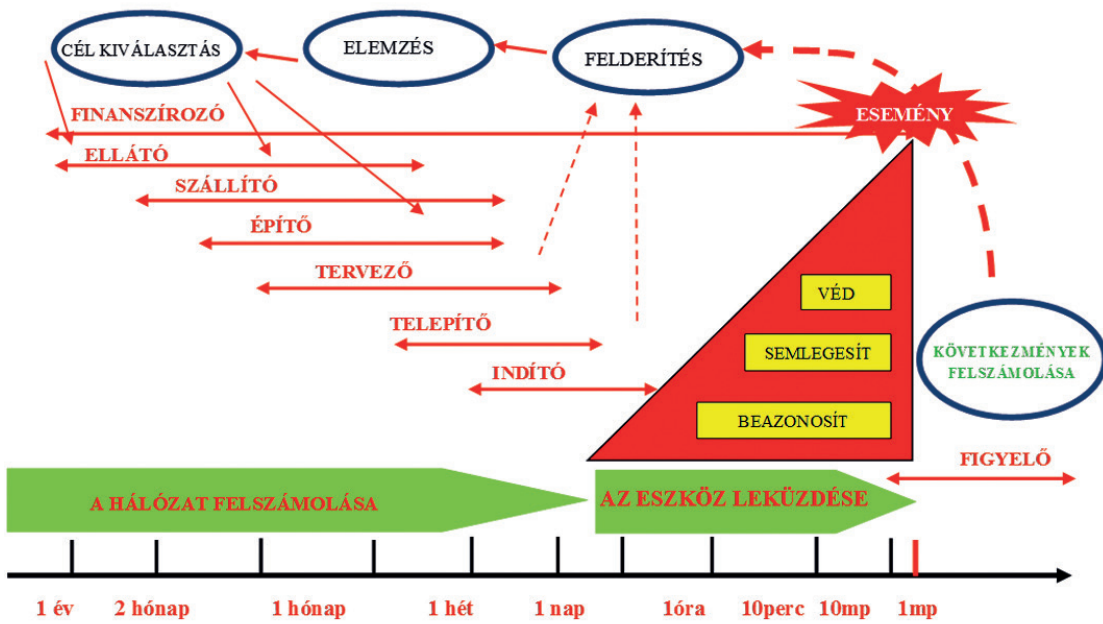

1. ábra. Az IED elleni harc folyamata

Forrás: a szerzők szerkesztése John E. McFee (szerk.): Observations on Military Exploitation of Explosives Detection Technologies. 2011. május. alapján

A NATO-doktrína az IED elleni harcot a fentieken túl kiegészíti a csapatok felkészítésével, amely az általános felkészítés és a biztonsági rendszabályok ismerete mellett a specifikus hadszíntéri felkészítést is tartalmazza. ${ }^{42}$

Az IED felderítésének hatékonyabbá tételére indított kutatások rámutattak, hogy a robbanószerkezetek, különösen az IED-k jelentette veszély alapvetően a robbanóanyag-tartalmukból származik, nem pedig a hozzájuk kapcsolódó másodlagos tulajdonságokból, mint például a burkolat anyaga vagy az indító mechanizmusok. Így optimálisan a felderítést végző eszközökre lehetne olyan szenzorokat telepíteni, amelyeket kifejezetten a robbanóanyagok detektálására terveztek. Az ilyen érzékelők valóban akna- vagy IED-detektorok lennének, csökkentve a környezet szennyezettségéből és az egyéb okokból eredő hamis riasztásokat. Ez gyakori probléma a fenyegetések másodlagos tulajdonságait észlelő technológiákkal, például az elektromágneses indukciós érzékelőkkel, amelyek az aknák felderítésekor még hatásos eszköznek bizonyultak. A felderítés végrehajtásához, vagyis a veszélyt jelentő eszközök detektálásához a következőkre van szükség:

1. a célpont fizikai tulajdonságainak beazonosítása, amelyek lehetővé teszik a megkülönböztetést a cél és a környező háttéranyagok között,

2. a célpontra jellemző tulajdonságok kiaknázása az erre a célra tervezett detektor fejlesztésével és alkalmazásával.

42 Allied Joint Publication AJP-3.15. Edition C, Version 1, Allied Joint Doctrine for Countering Improvised Explosive Devices. NATO STANAG 2295. (2016) i. m. 1. fejezet, 1.17. 
Az észlelés megvalósítására tett megállapítások alapvetően jellemzőek minden felderítési eljárásra, legyen az ásványfeltárás, vegyi vagy biológiai veszélyek felkutatása vagy robbanóanyagok felderítése.

Mindezek alapján a robbanásveszély észlelésének problémája három támogatandó fejlesztési területre bontható:

- anomáliák jelzése és lokalizálása,

- robbanóanyag jelenlétének megerősítése,

• a különböző típusú észlelő és felderítő rendszerek egymásra épülő rétegének integrációja.

Ez utóbbi rendszerben alapvető a többlépcsős, többszenzoros megközelítés, azaz az eszköz minél pontosabb felderítése és beazonosítása. Továbbá fontos szempont, hogy a felderítést végzők minél nagyobb biztonságban, azaz a lehető legnagyobb távolságra legyenek a potenciális fenyegetéstől. Ugyanakkor, amint a tanulmány bevezetőjében már jeleztük, a műveleti tempó, valamint a műveletek biztosítása érdekében végzett manőverek gyors, biztonságos végrehajtása fő szempontként jelenik meg a fejlesztésekben. A környezeti anomáliák felderítésére alakították ki az alapvetően MRAP-felépítésű ${ }^{43}$ járművekből álló út- és akadálymentesítő csoportot. ${ }^{44} \mathrm{~A}$ járművek és a kapcsolódó fejlesztések a robbanószerkezetek másodlagos összetevőjének - a burkolat vagy a gyújtószerkezet anyagának, azaz fémszerkezetek - detektálására, valamint a jármüre és annak kiegészítőire installált optikai szenzorok segítették a vizuális felderítést. Az IED-k fém összetevőinek felderítésére jó példa a Husky típusú járműre szerelt hagyományos és nagy érzékenységü impulzusos indukciós fémérzékelő rendszerek, mint a NIITEK VISOR 2500 típusú talajradar. ${ }^{45}$ Ugyanakkor a kezelő személyzet viszonylagos biztonságból - a jármű páncélvédettségéből - végezheti az IED-gyanús szerkezetek beazonosítását, valamint semlegesítését a jármüre szerelt vizsgálókar segítségével. ${ }^{46}$

A robbanásveszélyhez kapcsolódó másodlagos tulajdonságok kiaknázása, mint például a burkolat anyaga vagy a kapcsolódó vezetékek észlelése, a talajzavar detektálása GPR ${ }^{47}$ vagy infravörös (IR) képalkotással, elsősorban rádiófrekvenciás technikák alkalmazásával viszonylag sok hibával járt, különösen egy háborús hadszíntéren, ahol a talaj fémszennyeződése jelentős. Tehát a robbanószerkezetek alapvető anyagának, a robbanóanyagnak a detektálása, amely biztosítja a távfelderítési képességet, elengedhetetlenül szükséges. A korábban már említett fontos kritérium, hogy a műveletek végrehajtásának dinamikáját az IED észlelése megtöri, ezáltal a parancsnokot választás elé állítja:

43 Az IED-támadások ellen speciálisan kialakított járművek: Mine Resistance Ambush Protected angol kifejezés rövidítése. Forrás: Csurgó (2019) i. m.

44 Szabó-Kovács-Kovács (2016) i. m. 2-11.

45 Szabó-Kovács-Kovács (2016) i. m. 3.

46 Szabó-Kovács-Kovács (2016) i. m. 5.

47 Nagyfrekvenciás elektromágneses hullámokat alkalmazó földradar vagy geológiai radar. A Ground-Penetrating Radar angol kifejezés rövidítése. 
- manőverezni és megkerülni a potenciális veszélyt, annak különösebb vizsgálata nélkül,

- vagy tovább vizsgálni a fenyegetést müködési területen belül saját erőforrásokkal,

- vagy biztosítani a helyszínt és átadni a területet a felderítésre és mentesítésre felkészültebb szakalegységnek.

A döntési kritériumok, amelyek a müvelet végső kimenetéhez vezetnek, a küldetés specifikációi lesznek, de általános megfigyeléseket lehet tenni, állapította meg a kutatást végző csoport. ${ }^{48}$ Rámutatva, a megkerülés lehetősége megőrzi a műveleti tempót a potenciális fenyegetések hátra hagyásának rovására, míg a másik két esetben a magas fokú biztonságért cserébe leállítja a műveletet, amely nagy valószínűséggel időt biztosít a szemben álló fél részére a kezdeményezés megragadására.

Tehát a kulcskérdés a műveletek eredményessége, valamint a személyi állományra nehezedő veszély csökkentése érdekében a pontos beazonosítás. A veszélyt jelentő eszközök másodlagos tulajdonságainak beazonosítására alkalmas eszközök - tekintettel a korábban említett korlátokra - nagy valószínűséggel sokkal több potenciális IED-t jelölnek meg. Ennek kiküszöbölésére a robbanóanyag-tartalom ellenőrzése lehet a megoldás. Ez a lépés nem mindig szükséges, a veszélyeztetett területeket egyszerüen meg lehet jelölni vagy a célt eltávolítani, semlegesíteni a helyszínen, annak valós veszélyességétöl függetlenül. Olyan helyzetekben, amikor ajánlatos a magas fokú biztonság fenntartása, szükség lehet a robbanóanyag-tartalom jelenlétének vagy hiányának ellenőrzésére. Ez a helyzet akkor fordulhat elő, ha a célpontok például elökészített útfelületen vannak, amelyet időigényesen javítanának meg a megsemmisítési vagy eltávolítási múvelet után. Hasonló a helyzet, ha nagy területeket kell megtisztítani, és annak megkerülése nem biztosítja, illetve veszélyezteti a küldetés sikerét. Továbbá amikor egy adott terület mentesítése szükségessé vált, kívánatos csökkenteni az elsődleges érzékelők hamis riasztásait, hogy ne merítsék ki a feltáráshoz és a hatástalanításhoz rendelkezésre álló erőforrásokat.

A robbanóanyag-tartalom megerősítése nem támaszkodhat másodlagos mutatókra, ezért az alkalmazott technikáknak képesnek kell lenniük a robbanásveszély érzékelésére. Az ilyen technológiát alapvetően két csoportra osztjuk, amit a 2. ábrával szemléltetünk.

48 McFee (2011) i. m. 


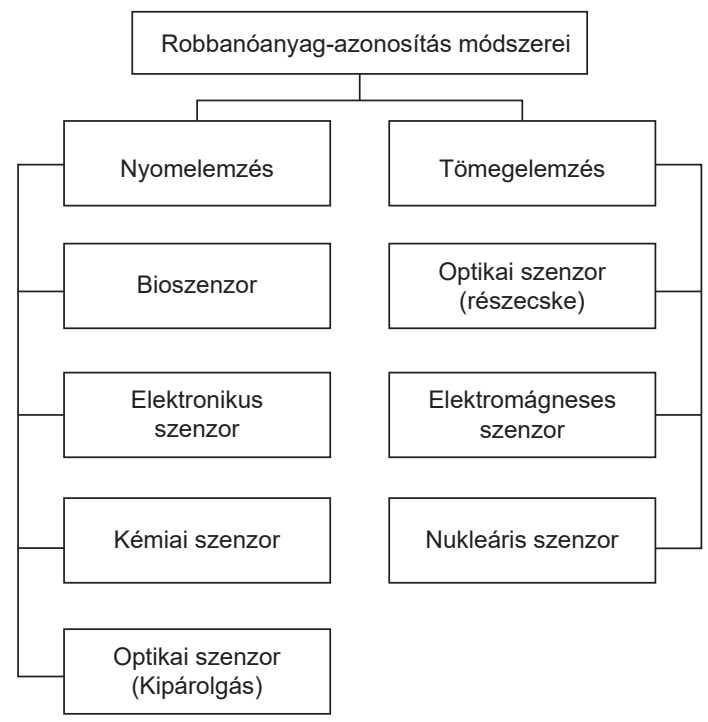

2. ábra. A robbanóanyag-azonosítás módszerei

Forrás: a szerzők szerkesztése McFee (2011) i. m. alapján

A robbanóanyagok kimutatásának alapvetően két módszerét különböztetjük meg:

- nyomdetektorokkal végzett felderítést, amelyek detektálják a levegőben vagy az adott tárgy felületén található robbanásveszélyes gőzt vagy részecskéket, amelyek potenciálisan robbanóanyag jelenlétére utalnak, valamint

- a tömegelemzésre alapuló detektorokat, amelyek rendeltetése a céltömeg robbanóanyag-tartalmának kimutatása, illetve nukleáris anyag beazonosítása.

A nyomelemzők különböző fokú szennyezettséget, lokalizációt és/vagy megerősítést nyújtanak. A tömegdetektorok/spektrométerek általában csak lokalizációt vagy megerősítést biztosítanak, azonban ez a korlátozás megváltozhat a képalkotást és a spektroszkópiát ötvöző THz-technológia ${ }^{49}$ megjelenésével. A technológia a különböző anyagok által generált és jól azonosítható lenyomataira épül, amely lehetőséget biztosít a több összetevőt tartalmazó tárgyak, mint például a rögtönzött robbanószerkezetek anyagainak szétválasztott azonosítására. Ugyanakkor a robbanóanyagok minél pontosabb detektálására kialakított szenzorok katonai alkalmazása, amely döntően nem stacioner alkalmazást jelent, még várat magára. Jelenkorunk műveletei időbeni gyors végrehajtásának szükségszerű velejárója az IED-k gyors, távoli, a katona fizikai jelenléte nélküli felderítése. A robbanóanyag kimutatására kifejlesztett szenzorok katonai alkalmazásra alkalmas autonóm eszközökön történő elhelyezése lesz vél-

49 Bunyitai Ákos: Terahertz-es technológia alkalmazása a biztonságtechnikában. Hadmérnök, 5. (2010), 2. 
hetően a megoldás. Számos ország, illetve a NATO is, együttmüködve kutatóközpontokkal és egyetemekkel folytatja az autonóm eszközökre szerelt robbanóanyag detektálása lehetőségeinek vizsgálatát. ${ }^{50}$

\section{5. Összegzés}

A 21. században vizsgált katonai műveletekben, tekintettel a résztvevők közötti nagyfokú technológiai különbségekre, aszimmetria alakult ki. A hadviselő felek közötti technológiai különbségek ellensúlyozására a gyengébb fél előszeretettel alkalmazza az IED-t vagy rögtönzött robbanószerkezetet a magasabb fejlettségi szinten álló ellenfél mozgásának, manővereinek akadályozására. A szerzők jelen tanulmányban rámutattak, hogy az aszimmetrikus müveletekben alkalmazott rögtönzött robbanószerkezetek döntően befolyásolják a mozgás- és manőverszabadságot. Bizonyítva, hogy az IED mint fegyver olyan jellemzőkkel rendelkezik, amelyek alkalmazójának nemcsak harcászati, de adott esetben műveleti vagy stratégiai szintű sikerek elérését is lehetővé teszi. A gyengébb fél által elért sikerek rákényszerítik az erősebb felet az IED jelentette fenyegetésből származó veszélyek elleni védekezésre. Az IED jelentette fenyegetés kiküszöbölésének egyértelmű iránya azok gyors, pontos és biztonságos azonosítása. A szerzők bemutatták az IED-k detektálásának jelenlegi irányát, valamint bizonyították, hogy a műveleti tempó és a műveletek biztosítása érdekében végzett manőverek időbeni biztonságos végrehajtása szükségessé teszi az IED-k hatékony és fizikai érintkezés nélküli felderítését, semlegesítését. Bár ígéretes kutatások folynak a fenyegetésként azonosított eszközök robbanóanyag-tartalmának biztonsági távolságon kívülröl történő kimutatására, azok katonai alkalmazása terén még sok munka van hátra.

A tanulmány a „Kooperatív Doktori Program Doktori Hallgatói Ösztöndij” pályázat segítségével valósult meg, amelyet az Innovációs és Technológiai Minisztérium, a Nemzeti Kutatási, Fejlesztési és Innovációs Alapból támogat.

\section{Felhasznált irodalom}

„Mission Accomplished". Telegraph. Online: www.telegraph.co.uk/news/worldnews /middleeast/ iraq/3447776/Bush-Regrets-Mission-Accomplished-Banner.html

Ágh Attila: Konfliktusok, háborúk. Budapest, Zrínyi, 1989.

Allied Joint Publication AJP-3.15. Edition C, Version 1, Allied Joint Doctrine for Countering Improvised Explosive Devices. NATO STANAG 2295. Brussels, NATO Standardization Office (NSO), 2016.

Al-Qaeda. Britannica. Online: www.britannica.com/topic/al-Qaeda-in-Iraq

At least 134 killed in attacks across Iraq. CNN.com, 2006. Online: http://edition.cnn.com/2006/

WORLD/meast/01/05/iraq.main/

50 Three Nato scientific technologies for IED detection tested in Italy. Army Technology, 2018. 
Bucsák Mihály - Csurgó Attila - Horváth Tibor - Láng László - Molnár Sándor - Posta Lajos - Szatai Zsolt - Vörös Mihály: 70 év az életveszély árnyékában. A magyar tüzszerész-és aknakutató alakulatok története 1945-2015. Budapest, Zrínyi, 2015.

Bunyitai Ákos: Terahertz-es technológia alkalmazása a biztonságtechnikában. Hadmérnök, 5. (2010), 2. 73-85. Online: http://hadmernok.hu/2010_2_bunyitai.pdf

Csurgó Attila: A rögtönzött robbanószerkezetek által teremtett müveleti környezet hatása a mozgásszabadságra, az erők megóvása érdekében végrehajtott fejlesztésekre. Honvédségi Szemle, 147. (2019), 6. 42-53. Online: https://doi.org/10.35926/HSZ.2019.6.4

Fateful Choice on Iraq Army Bypassed Debate. The New York Times, 2008. Online: www.nytimes. com/2008/03/17/world/middleeast/ 17bremer.html

Forgács Balázs: In memoriam Kovács Jenő. Hadtudomány, 19. (2009), 1-2. 105-112. Online: http://mhtt. eu/hadtudomany/2009/1_2/105-112.pdf

Forgács Balázs: Napjaink hadikulturái (A hadviselés elmélete és fejlődési tendenciái a modern korban). Doktori értekezés. ZMNE-KLHK/HDI, 2009. Online: http://docplayer.hu/4930393-Napjaink-hadikulturai-a-hadviseles-elmelete-es-fejlodesi-tendenciai.html

Forgács Balázs: A háború és a politika viszonyrendszere. In Gőcze István (szerk.): A háború és a politika viszonyrendszere. Budapest, Dialóg Campus, 2017.

Fowl, Kyle-Roger Davies: What are IEDs? A review of the different types of IEDs that exist with a focus on recent developments in IED usage. AOAV, 2016. Online: https://aoav.org.uk/2016/ieds-reviewdifferent-types-ieds-exist-focus-recent-developments-ied-usage/

Hyde-Bales, Rob: The improvised Explosive Device - a defining component of $21^{\text {st }}$ century conflict. Counter-IED Report, London, Delta Business Media Ltd., 2018.

Kovács Zoltán: Az improvizált robbanóeszközök főbb típusai. Müszaki Katonai Közlöny, 22. (2012), 2. 37-52. Online: https://folyoirat.ludovika.hu/index.php/mkk/article/view/2804/2063

Mcfee, John E. (szerk.): Observations on Military Exploitation of Explosives Detection Technologies. 2011. május. Online: https://doi.org/10.1117/12.886391

Morris, R. Victor: Grading Gerasimov: Evaluating Russian Nonlinear War Through Modern Chinese Doctrine. Small War Journal, 2015. Online: https://smallwarsjournal.com/ jrnl/art/grading-gerasimov-evaluating-russian-nonlinear-war-through-modern-chinese-doctrine

NATO Tüzszerész kiválósági központ. (EOD COE Trencin, Szlovákia) Házi készítésű robbanóanyagok tanfolyama - Basic (HME-B) Course 2019. EOD COE. Online: www.eodcoe.org/en/news/home-made-explosives-basic-hme-b-level-course-2019.html

Operation Iraqi Freedom/Second Persian Gulf War. Britannica. Online: www.britannica.com/event/ Iraq-War

Resperger István - Kiss Álmos Péter - Somkuti Bálint: Aszimmetrikus hadviselés a modern korban. Kis háborúk nagy hatással. Budapest, Zrínyi, 2013.

Somkuti Bálint: A negyedik generációs hadviselés - az érdekérvényesités új lehetöségei. Doktori értekezés. Budapest, NKE, HHK, HDI, 2012. Online: https://doi.org/10.17625/NKE.2012.019

Szabó Sándor - Kovács Tibor - Kovács Zoltán: Az utak, területek akadálymentesítése III. Müszaki Katonai Közlöny, 25. (2015), 1. 4-18. Online: https://folyoirat.ludovika.hu/index.php/mkk/article/ view/2281/1548

Szabó Sándor - Kovács Tibor - Kovács Zoltán: Az utak, területek akadálymentesítése IV. Müszaki Katonai Közlöny, 25. (2015), 2. 116-130.

Szabó Sándor - Kovács Tibor - Kovács Zoltán: Az utak, területek akadálymentesítése V. Müszaki Katonai Közlöny, 25. (2015),3. 2-9. Online: https://folyoirat.ludovika.hu/index.php/mkk/article/ view/2474/1745

Szabó Sándor - Kovács Tibor - Kovács Zoltán: Az utak, területek akadálymentesítése VI. Müszaki Katonai Közlöny, 25. (2015), 3. 10-20. Online: https://folyoirat.ludovika.hu/index.php/mkk/article/ view/2475/1746 
Szabó Sándor - Kovács Tibor - Kovács Zoltán: Az utak, területek akadálymentesítése VII. Müszaki Katonai Közlöny, 26. (2016), 1. 2-11. Online: https://folyoirat.ludovika.hu/index.php/mkk/article/ view/2181/1450

Szendy István: Hadelmélet és Katonai Müveletek. I. kötet. A katonai müveletek elmélete és gyakorlata. Budapest, Nemzeti Közszolgálati és Tankönyvkiadó, 2013.

The Taliban, regrouped and rearmed. The Washington Post, 2006. Online: www.washingtonpost.com/ wp-dyn/content/article/2006/09/08/AR2006090801614_2.html? noredirect=on

Three Nato scientific technologies for IED detection tested in Italy. Army Technology, 2018. Online: www.army-technology.com/news/nato-technologies-ied-detection-test/

Tranchemontagne, Marc: The Enduring IED Problem, 2016. Online: https://ndupress.ndu.edu/Portals/68/ Documents/jfq/jfq-80/jfq-80_153-160_Tranchemontagne.pdf 